\title{
Implementation of Financing Agreement Musyarakah Against Customer in Sharia Bank Periode 2018 (Study: Bank Pembiayaan Rakyat Syariah Bangka Belitung)
}

\author{
Yudi Setiawan $^{1 *}$, Mira Karina ${ }^{2)}$ \\ ${ }^{1}$ Universitas Muhammadiyah Yogyakarta \\ ${ }^{2}$ Yayasan Miftahul Jannah \\ * Email correspondence: yudiudink7@gmail.com
}

Abstract

Agreement is a where action one person or people bind your self against or more persons. In general people are free to make agreement not tied to particular shape can be made oral or writtrn. Financing is provision of funds or bill whinc in the equation with it. Musyarakah is a partnership agreement thet the benefits and risk will be borne together as agreed. Customers are parties who use the services of islam bank and UUS, syariah bank is a that runs is business activities based on syariah principles. Research method used in this research Empirical Juridical. The perpuse of this study is to find out how the Implementation in musyarakah financing and what are the obstcles that occur in the implementation, the implementation of the musyarakah financing agreement, implementation on the basis of syariah principles and agreement of bots parties, then in the implementation there are barriers thet the customers in this case does not perform it's obligation in accordance eith the contents of the agreement thet has been made. In setting the matter, the ways of deliberation between the two parties do not find an agreement on the matter, then to resovle the matter is pursued by legal means throught the courts or through the arbitration body. Problem in change of islam is conducted in tree ways, nemaly though the road of peace, trough thes road the bank and with rescheduling done, then two road of arbitration, and then though the road of justice.

Keywords: Agreement, Musyarakah Financing, Customers, Syariah Bank

Citation suggestions: Setiawan, Y., \& Karina, M. (2021). Implementation of Financing Agreement Musyarakah Against Customer in Sharia Bank Periode 2018 (Study: Bank Pembiayaan Rakyat Syariah Bangka Belitung). Jurnal Ilmiah Ekonomi Islam, 7(02), 840-847. doi: http://dx.doi.org/10.29040/jiei.v7i2.2399

DOI: $\underline{\text { http://dx.doi.org/10.29040/jiei.v7i2.2399 }}$

\section{INTRODUCTION}

The development of Sharia banking in Indonesia after Law No. 10 of 1998 concerning amendments to Law No. 7 of 1992 on banking took place so rapidly. The development is one of the factors because through Law No. 10 of 1998 the policy of national banking law development using dual banking system, which is allowed by Conventional Commercial Banks to provide Sharia services by first establishing Sharia Business Unit (UUS) in the central office. Banking Institutions as one of the financial institutions that have strategic value in the economic life of a country. The institution is intended as an intermediary for parties who have excess funds (surflus of funds) with parties who lack of funds. Thus, banks will be engaged in credit activities and various services provided. The
Bank serves financing needs and launches system mechanisms for all financial sectors.

The activities of banking institutions in general are carried out by actors who according to their functions and business objectives can be distinguished, namely in the form of central banks (central banks) and commercial banks (commercial banks). Commercial banks or commercial banks in their activities are built and supervised by the central bank, while the central bank in carrying out its basic duties at the discretion of the government.

In some ways, Conventional Banks and Sharia Banks have similarities, especially in terms of money receipts, transfer mechanisms, computer technology used, general requirements for obtaining financing such as KTP, NPWP, Proposals, Financial statements, and so on. However, there are many fundamental 
differences between the two. The difference concerns the legal aspects, organizational structure, financed business, and work environment. In addition to the differences, sharia banks and conventional banks have comparisons namely, Sharia Banks: Making halal investments only, based on the principle of profit sharing, buying and selling, or renting, profit in falah oriented, relationships with customers in the form of partnership relationships, collecting and disbursing funds must be in accordance with the Fatwa of the Sharia Supervisory Board. While conventional banks: Investments that are halal and haram, using interest devices, profit oriented, relationships with customers in the form of debtor-debtor relationships, there is no similar board (Antonio. 2001).

Banking institutions with their functions, among others, as intermediaries of parties that have excess funds (surflus of funds) with parties that lack of funds; as well as serving the needs of financing and launching payment system mechanisms for all sectors of the community economy, according to sociology, banking is recognized as a social institution. In the sense that banking is a form of a set of norms of all levels concerning basic human needs (Antonio. 2001).

Parties who use the services of banks in the Banking Law are commonly referred to as customers. Customers who are overfunded will deposit their funds in banking institutions in the form of current accounts, savings accounts and deposit accounts. In this case, the banking institution performs its function as an intermediary by providing credit to customers who need funds through the bank because customers who need funds will be very difficult to meet directly with customers who are overfunded. With banks, customers who need funds will easily get funds through the bank by giving credit to customers who need funds based on the rules in the bank.

Credit is the provision of money or bills that can be equated with it, based on the agreement or loan agreement between the bank and other parties that requires the borrower to pay off his debt after a certain period of time with interest (Law No. 10 of 1998: Article 1 number 1). In providing credit to customers, based on sharia principles the bank must have confidence based on an in-depth analysis of the intention and ability and ability of the debtor's customers to pay off their debts or return the financing in accordance with the agreement. To obtain these beliefs, before providing credit, the bank must conduct a careful assessment of the character, capability, capital, collateral, and business prospects of the debtor's customers. So in providing such credit the bank must apply the principle of prudence in order to reduce the risks that will occur.

In providing credit to customers who need funds based on sharia principles can be an agreement agreed by both parties in the form of a credit agreement. In the Civil Code there is no provision on how an agreement should form, meaning that the agreement can be set forth in the form of written agreements and unwritten agreements (Melinda. 2015).

Credit agreements are one of the most important aspects of lending, without credit agreements signed by banks and debtors, there is no credit agreement. A credit agreement is a bond between a bank and a debtor whose contents determine and regulate the rights and obligations of both parties in connection with the provision or loan of credit (borrowing money). Credit agreements are usually followed by a guarantee agreement, then the credit agreement is the principal or principle while the guarantee agreement is a follow-up agreement or assesoir means there is and the expiration of the guarantee agreement depends on the principal agreement (credit agreement). The credit agreement is valid since it was signed by both parties, creditors and debtors (Sutarno, 2003).

Financing is the provision of funds or bills that are equated with it in the form of profit sharing transactions in the form of mudharabah and musyarakah; rental transactions in the form of ijarah or buy rent in the form of ijarah muntahiya bittamlik; trade transactions in the form of murabahah receivables, greetings, and istishna; loan transactions in the form of qardh receivables; and transaction of rental services in the form of ijarah for multi-service transactions. Based on the agreement or agreement between Sharia Bank and/or UUS and other parties that require the financed party and/or given a fund facility to return the funds after a certain period of time in exchange for ujrah, without reward, or revenue sharing (Law of the Republic of Indonesia Number 21 of 2008 concerning Sharia Banking).

In other words, if sharia banks and customers make agreements whose formal form is based on Article 1320 of the Civil Code and Article 1338 of the Civil Code, but the content of the material or substance is based on sharia provisions, then the agreement can be said to be valid, both in terms of national law and sharia law. In practice, the preparation of an agreement between sharia banks and 
customers, from a positive legal side, in addition to referring to the Civil Code must also refer to Law No. 10 of 1998 on Amendments to Law No. 7 of 1992 on Banking, and Law No. 21 of 2008. Meanwhile, from the sharia side, the parties are guided by the Fatwas of the National Sharia Council of the Indonesian Ulema Council. (Melinda. 2015).

In Sharia banking, actually the use of the word borrow is not appropriately used due to two things. First, borrowing is one of the methods of financial relations in Islam. There are still many methods taught by Shariah in addition to loans, such as buying and selling, revenue sharing, renting, and so on. Second, in Islam, borrowing is a social contract, not a commercial contract. That is, if a person borrows something, it should not be required to provide additional principal on the loan. (Antonio. 2001).

From the above exposure, a problem can be taken, namely about the Implementation of Musyarakah Tehadap Customer Financing Agreement at Sharia Bank and what are the obstacles (problems) in the Implementation of Musyarakah Financing Agreement at Sharia Bank?

\section{RESERCH METHODS}

Research method is a reference in conducting a research, where in this case writing using the following research methods:

This type of research is taken from this study using normative legal research type. Normative Law Research is a legal research that places the law as a building system of norms in the form of principles, norms, rules of legislation, court decisions, agreements and doctrines (teachings). Legal research materials sought with literature research (including interviews with resource persons). In accordance with the type of research above, the approach made in this study is the Library Approach. In this study, the use of normative research method is by reviewing and analyzing the results of Pustaka study and interview results with resource persons conducted by the author.

\section{DISCUSSION AND RESEARCH RESULTS}

\subsection{Discussion}

\section{a. Treaty Theory}

In the Civil Code, Article 1313 defines that an agreement (agreement) is an act in which one or more persons bind themselves to one or more persons. The person who makes a covenant must be capable according to the law. In principle, every person who has grown up or is a returning and healthy mind, is capable according to the law. In Article 1330 of the Civil Code are referred to as people who are not capable of making an agreement that is, immature people, those who are put under women in matters stipulated by the Act, and all persons to whom the Act has prohibited making certain agreements (Civil Code Article 1313. Part 1).

In sharia banks, the contract has worldly and ukhrawi consequences because the contract is done under Islamic law. Often the customer dares to violate the agreement / agreement that has been done if the law is only based on a positive law, but not so if the agreement has liability until yaumil qiyamah later.

Such as contracts in Sharia banking, both in terms of goods, transaction actors, and other provisions, must meet the provisions of the agreement, such as the following. In the harmony of the contract must meet several elements, namely sellers, buyers, goods, Akad/ijab-qobul. While in the Terms of contract, namely goods and services must be halal so that transactions on goods and services that are illegal become null and void for the sake of sharia law, the price of goods and services must be clear, the place of delivery must be clear because it will have an impact on transportation costs, the goods transacted must be fully in ownership. It is not permissible to sell something that has not been owned or controlled as happened in a short sale transaction in the capital market (Antonio. 2001).

\section{b. Bank Secret Theory}

Provisions on bank secrets are a very important thing for the depository and depositor customers as well as for the interests of the bank itself, because if this depository customer does not trust the bank where he keeps his deposit of course he will not want to be his customer. Therefore, as one of the financial institutions that serves to raise funds from the public in the form of deposits, it is appropriate for banks to implement. the bank's confidential provisions consistently and responsibly in accordance with applicable laws and regulations to protect the interests of customers. There are two theories about bank secrets.

The Bank's Secret Theory of Absolute Ironfat, According to this theory the bank has an obligation to keep secrets or information about its customers known to the bank because of its business activities under any circumstances, under ordinary circumstances or under exceptional circumstances. This theory greatly 
highlights the interests of individuals, so the interests of the state and society are often overlooked.

Bank Secret Theory that is Relative or Nisbi, According to this theory the bank is allowed to open secrets or give information about its customers, if for urgent purposes, for example for the benefit of the state or legal interests. This theory is widely embraced by banks in many countries in the world, including Indonesia. The existence of exceptions in the provisions of bank secrets allows for certain interests a body or agency is allowed to request information or data about the financial condition of the customer concerned in accordance with the provisions of applicable legislation (Hermansyah. 2006).

\section{c. Legal Principles in Sharia Agreements}

In sharia treaty law there are several principles of agreement that become the basis of the enforcement and implementation of a contract and or agreement. The principles of the covenant are divided into two, namely the principles of covenants that do not result in law and its general nature and the principles of covenants that result in law and its special nature. The principles of agreement in Islamic law are:

1) Basic Ibahah (Mabda' al-Ibahah)

The principle of Ibahah is the general principle of Islamic law in the field of muamalat in general. This principle is formulated in adagium "in principle all things can be done until there is evidence that prohibits it." This principle is the opposite of the principle that applies in the matter of worship. In Islamic law, for acts of worship there is a principle that valid forms of worship are the forms mentioned in the Shariah evidences. One cannot make up a new form of worship that was never determined by the Prophet (s). New forms of worship made without ever being taught by the Prophet (s) are called heresy and invalid law (Anwar. 2007). On the contrary, in muamalat actions apply the opposite principle, namely that everything is valid to be done as long as there is no strict prohibition on it. When associated with legal action, particularly agreements, then it means that any legal action and agreement can be made to the extent that there are no specific restrictions on such agreements.

2) Principle of Freedom of Berakad (Mabda' Hurriyah at-Ta'aqud)

Islamic law recognizes freedom of speech, which is a legal principle that states that anyone can make any type of contract without being bound to the names specified in the Sharia Law and insert any clause into the contract made that is in accordance with its interests as far as it does not result in eating other's property by false means. However, in the environment of the different sects there is a difference of opinion regarding the extent of the freedom. Nas-nas Al-Qur'an and sunnah of the Prophet (s) and the rules of Islamic law show islamic law adheres to the principle of freedom of religion. This principle of freedom of speech is a further concreteization and an even more assertive specification of the principle of ibahah in muamalat. The existence of the principle of freedom of worship in Islamic law is based on several evidences, among others, the Word of God, "O believers, keep the covenants" [QS. 5:1], The Prophet (peace and blessings of Allaah be upon him) said: "The Muslims are always faithful to their terms." Sabda Nabi Saw., "Whoever sells a date palm tree that has been mated, then the fruit is for the seller [not sold], unless the buyer requires other.", The rule of Islamic law, in principle this agreement is the agreement of the parties and the result of the law is what they set upon themselves through the promise. (Anwar. 2007)

Freedom to make an agreement in Islamic law is not absolute, melaikan limited. In Islamic law, the restriction is with the "prohibition of eating other's property by false way" as stated in QS. 4: 29 . What is meant by eating the property of others by false means is to eat the property of others in a way that is not allowed and invalid according to sharia law, either directly prohibited in the Nas either or based on ijtihad on the nas. In general, it can be said that eating property by false way is contrary to public order and decency. However, public order and decency in Islamic Law are broader, because they include the prohibition of usury, gharar and the terms of the agreement that fasid.

3) Principle of Consensualism (Mabda' arRadha'iyyah)

The principle of consensualism states that for the creation of an agreement is sufficient with the achievement of the word agreement between the parties without the need for certain formalities to be fulfilled. In Islamic law in general the agreements are consensual. Islamic Jurists usually infer the principle of consensualism from the following legal evidences, the Word of Allah, " $O$ 
you who have faith, unless it is done by exchange based on mutual consent among you" [QS. 4: 29], He said, "Then if they give you a portion of the dowry on the basis of pleasure, So eat of it as a good and good provision." [QS. 4.4], Sabda Nabi Saw, actually the trade is based on the agreed word [Hadith narrated by Ibn Hibban and Ibn Majah], The Rule of Islamic Law, In principle the agreement (contract) is the agreement of the parties and the result of the law is what they set by promise.

4) The Principle of Promise is Binding

In the Qur'an and hadith there are many orders to fulfill the promise. In the suggestion of jurisprudence, "the commandment basically indicates mandatory". This means that the promise is binding and must be fulfilled. Among the verses and hadiths referred to are, The Word of God, “... and fulfill the promise, verily it shall be held accountable" [QS. 17:34], Asar of Ibn Mas'ud, the promise is debt, Verse QS. 5: 1 and Hadith alHakim quoted in sub C. 2.1) and 2.2) above.

5) Principle of Balance (Mabda' at-Tawazun fi alMu'awadhah)

Although factually there is rarely a balance between the parties in the transaction, but islamic treaty law still emphasizes the need for that balance, both the balance of what is given and what is accepted muapun balance in carrying risks. The principle of balance in the transaction (between what is given and what is received) is reflected in the cancellation of an agreement that experiences a striking performance imbalance. The principle of balance in shouldering risk is reflected in the prohibition against usury transactions, where in the concept of usury only debtors who bear all risks for business losses, while creditors are free at all and must get a certain percentage even when the funds experience negative returns. (Anwar. 2007)

6) Basic Benefits (Not Burdensome)

On the basis of benefit, it is intended that the agreement made by the parties aims to create benefits for people and should not cause harm (mudharat) or burdensome circumstances (masyaqqah). If in the implementation of the contract there is a change in circumstances that can not be known before and bring fatal losses to the parties concerned so burdensome, then the obligation can be changed and adjusted to a reasonable extent.
7) Trust Principle

On the basis of trust, it is intended that each party must be in good faith in transacting with the other party and it is not allowed for either party to exploit the ignorance of its partners. In Islamic law, there is a form of agreement called a trust agreement, one of which is the party that relies on honest information from the other party to make a decision to close the agreement in question. Among the provisions, is that lying or concealment of information that should be submitted can be the reason for the cancellation of the contract if in the future it turns out that the information is not true that has prompted the other party to close the agreement.

8) Principles of Justice

Justice is the goal that all laws want to realize. In Islamic Law, direct justice is an order of the Qur'an that confirms, "Be just, for it is nearer to taqwa" [QS. 5:8]. (Anwar. 2007). Justice is the joint of any agreement made by the parties. Often the modern dizaman contract is closed by one party with the other party without him having the opportunity to negotiate the contract clause, because the contract clause has been standardized by the other party.

\subsection{Research Results}

\section{a. Implementation of Musyarakah Financing Agreement at Sharia Bank}

Regarding the musyarakah financing agreement there is a stage in the implementation of the agreement. In general, a covenant is defined as an act in which one or more persons bind themselves to one or more others. In making an agreement, of course there are conditions that must be met by the parties concerned. Covenants can be distinguished in various ways so that various covenants arise. In the implementation of musyarakah financing, the implementation is included in a variety of reciprocal agreements.

Because a reciprocal agreement is an agreement made by laying down rights and obligations to both parties who make an agreement, such as a sale and purchase agreement Article 1457 of the Civil Code and a lease agreement Article 1548 of the Civil Code. (Smart Dictionary of Sharia Economy) financing is defined as the provision of funds or bills that are equated with it in the form of, profit sharing transactions in the form of mudharabah and musyarakah, rental transactions in the form of ijrah 
muntahiyah bit tamlik, trade transactions in the form of mudharabah receivables, greetings, and istish'na, loan transactions in the form of qardh receivables and rental transactions in the form of ijrah for multiservice transactions. In the study (Yahya and Agunggunanto, 2014) that business support is the main motivation for financial institutions to implement profit sharing financing methods. In this case the respondents stated that interest payments sometimes create difficulties for businesses. The unusuality of risk sharing with creditors is the main reason for the unpreparedness of financial institutions to give credit based on revenue sharing. The growth in demand for these funds is the most significant factor in distinguishing between financial companies that are ready to provide credit based on profit sharing.

Musyarakah is one of the types of financing in Sharia banking. Musyarakah itself in its implementation based on the principle of revenue sharing between the customer and the child. So even though the bank as a provider of funds in the business, but the customer must have funds also in terms of its implementation, to be able to carry out joint efforts and the results of the business using the principle of profit sharing. The purpose of this financing is to improve the economy of the people, the availability of funds for business improvement, increase productivity, open new jobs, the occurrence of income distribution. As for micro, financing aims to, efforts to maximize profits, efforts to minimize risk, utilization of economic resources, overfunded dealers.

(Karim, 2007) Musyarakah is included in the type of financing in Sharia Banks, Fiqh analysis and Finance, because in investment financing is given to customers for investment purposes, namely the need to increase capital for the procurement of rehabilitation, business expansion, or the establishment of new projects. The breadth of aspects that must be managed and supervised, so for sharia bank investment financing using musyarakah scheme.

In this case, the bank provides financing with the principle of inclusion, and gradually the bank releases the investment and the owner of the company will take over again, either by using the surplus cash flow created or by adding capital, both from existing shareholder deposits and by inviting new shareholders. Customers who lack business capital can get funds from customers who are overfunded in sharia banks. In borrowing funds customers obtain business funds from sharia banks, one of which is with funds provided by banks based on the principle of musyarakah financing. Financing with musyarakah principle is done with the approval and or agreement between the bank and the customer. From the results of research conducted at The People's Financing Bank of Bangka Belitung Sharia, agreements in musyarakah financing conducted and or made by banks and customers where the contents in the agreement have been made together and agreed by both parties who carried out the agreement. (Research at Bank Pembiayaan Rakyat Syariah Bangka Belitung 2018)

\section{b. Obstacles in the Implementation of Musyarakah Financing Agreement in Sharia Banks}

The obligations of the parties to an agreement are generally referred to as achievements. The achievement in an agreement is that a party who obtains the rights of the agreement also accepts obligations that are good from the right that obtains it, and on the contrary a party that assumes obligations also obtains rights that are considered as opposed to the obligations imposed on him.

In the implementation of an agreement of course the two parties have met the word agreement in terms of binding themselves on each other, and have agreed on what they have made in a treaty and or the content of the agreement made by both parties who are binding themselves. In the implementation, sometimes there are customers and or banks who violate the contents of an agreement, the form of violation varies according to what they agreed in the content of the agreement. (Results of research at Sharia People's Financing Bank in 2018).

Agreements made by both parties actually result in binding legal consequences, in accordance with applicable law and rules made by both parties. So if one of the parties does not heed the agreed agreement, then the party will accept the legal consequences in accordance with the rules or agreements that have been agreed. This is in line with research conducted (Musfiroh, 2016) explains that Islamic Banks seem to tend to be dominant in using musyârakah forms in trade for short periods of time, although other forms remain in use. In financing musyarakah capital contribution comes from the bank. The bank in this case oversees how the musyarakah business is run so that the banks ensure that they receive the initial return on investment provided along with the profits earned, and ask for various kinds of guarantees that are used to protect its interests in the business, with this 
guarantee it seems that the bank throws all the risks of musyarakah business to its partners, And set a time limit for the contract of musyarakah. There is no uniformity between Islamic banks in implementing the revenue sharing method, although the methods used are various but the essence is the same.

\section{CLOSING}

\subsection{Conclusion}

A covenant is defined as an act in which one or more persons bind themselves to one or more others. Bank pembiayaan Rakyat Syariah Bangka Belitung in terms of the implementation of musyarakah financing applies the same as the core of the agreement in general where the bank and customers in this case the implementation of making an agreement on the project based on the principle of musyarakah agreement. The Bank in this case as the capital giver provides capital based on sharia principles in accordance with the mutually agreed agreement, so that both the bank and the customer have their own rights and obligations to fulfill the contents of the agreement, agreements are made so that in such legal acts, no party will be harmed or there are rights and obligations that are not fulfilled.

Obstacles or problems that occur in the implementation after the agreement or agreement is done that is, usually in this case the customer or borrower's capital is not committed in terms of installment payments to the jointly agreed project. Here the customer is considered not committed in carrying out his obligations to the bohir commonly known as the project giver, this becomes a problem in the cooperation between the parties and the customer. Supposedly, the customer in this case must fulfill its obligations to the disbursement of mutually agreed funds, so that no one violates the content of the agreement / agreement made and also no party is harmed and the agreement does not encounter problems or problems so that in this case the implementation of the agreement between the customer and sharia banks runs in accordance with what is promised without any obstacles and or problems.

In solving the problem, Sharia People's Financing Bank usually solves the problem by going through deliberations, where before the deliberations held the bank gave a reprimand in the form of a warning letter to the customer who is troubled to fulfill its obligations in accordance with the contents of the agreement. Then in the deliberations, the bank and the customer both provide solutions to solve the problem so that the customer's obligations can be fulfilled. In order for the customer to resolve the obstacles or problems, to fulfill its obligations the bank usually reschedules or obligations of customers in the bank on the basis that the customer's source of income is still there and still has good faith to complete the financing.

\subsection{Advice}

The bank in this case the business capital giver to the customer did not find many problems, so the Sharia People's Financing Bank Banga Belitung can develop performance in the form of financing programs that make customers have the desire and convenience in conducting transactions or borrowing business capital to banks by not thinking about many risks. From the satisfaction and comfort of customers in transacting in Sharia Banks, customers do not hesitate to borrow capital or make transactions that will be sustainable without any problems that will occur and no party is harmed, until now in the implementation of musyarakah financing agreement has been effectively carried out by the Sharia People's Financing Bank Bangka Belitung.

In the case of disbursement of funds that are not committed or defaulted, many factors are the reason for the customer in payment or disbursement of funds related to the incorrect time. The bank should first find out what is the cause of the customer is not committed related to the time of disbursement of funds. Because here usually the bank does not know what causes the customer is not committed to the time of disbursement of funds related to the content of the agreed agreement.

\section{REFERENCES}

Ali, Zainuddin, 2010, Metode Penelitian Hukum, Jakarta: Sinar Grafika.

Amiruddin-Zainal Asikin, 2012. Pengantar Metode Penelitian Hukum, Jakarta: PT. RajaGrafindo Persada.

Antonio, Syafi'i, Muhammad, 2001, Bank Syariah dari Teori ke Praktek, Jakarta: Gema Insani.

Anwar, Syamsul, 2007, Hukum Perjanjian Syariah, Yogyakarta: PT. Raja Grafindo Persada.

Djumhana, Muhamad, 2012, Hukum Perbankan di Indonesia, Bandung: PT. Citra Aditya Bakti.

Hermansyah, 2006, Hukum Perbankan Nasional Indonesia, Jakarta: Kencana

Kitab Undang-Undang Hukum Perdata. 
Jurnal Ilmiah Ekonomi Islam, 7(02), 2021, 847

Lestari, Melinda, Nur, 2015, Sistem Pembiayaan Bank Syriah. Jakarta: Grafindo Books Media.

Mila Fursiana Salma Musfiroh, 2016, Musyarakah Dalam Ekonomi Islam (Aplikasi Musyârakah Dalam Fiqih Dan Perbankan Syariah), Jurnal Syariati, Vol. I, No. 03.

Muhammad, Abdulkadir, 2004, Hukum dan Penelitian Hukum, Bandung: PT. Citra Aditya Bakti.

Muchlis Yahya dan Edy Yusuf Agunggunanto, 2011, Teori Bagi Hasil (Profit And Loss Sharing) Dan Perbbankan Syariah Dalam Ekonomi Syariah, Jurnal Dinamika Ekonomi Pembangunan, Juli 2011, Vol. 1, No. 1.
Sutarno, 2003. Aspek-Aspek Hukum Perkreditan Padan Bank. Bandung: Alfabeta.

Sugiono, 2012. Metode Penelitian Kuantitatif, Kualitatif, dan R\&D, Cetakan ke-17. Bandung: Alpabet.

Subekti, 2005. Hukum Perjanjian. Jakarta: PT. Intermasa.

Umam, Khotibul, 2009, Trend Pembentukan Bank Umum Syariah Undang-Undang Nomor 21 Tahun 2008, Yogyakarta: BPFE-Yogyakarta.

Undang-Undang Republik Indonesia Nomor 10 Tahun 1998 Tentang Perubahan atas UndangUndang Nomor 7 Tahun 1992 Tentang Perbankan. 